\title{
Maggie's Deafening Silence: Femininity as a Masquerade in Henry James' The Golden Bowl
}

\author{
Ali Taghizadeh \& Forough Emam
}

English Department, Faculty of Arts, Razi University, Kermanshah, the Islamic Republic of Iran. Email: altaghee@zedat.fu-berlin.de

Received November o8, 2017; Revised February 06, 2018; Accepted February 15, 2018; Published May o6, 2018.

\begin{abstract}
In Henry James's The Golden Bowl, although Maggie Verver is in love with her husband, her silence, regarding his affair, is quite enigmatic. However, in the theory of masquerade, which Joan Riviere proposed in a 1929 seminal essay, this idea was deconstructed. According to the theory of masquerade, women submit to the social codes by wearing a mask of womanliness while at the same time surreptitiously following their own phallic desires. Therefore, even their typically virtuous act of silence can be understood as a womanly disguise which is inherently a masquerade. This paper aims to analyze Maggie's silence, despite the infidelity and betrayal shown to her by her friend and husband, in order to demonstrate how, according to Riviere, her silence and quietness are not signs of victimhood in the patriarchal society but only tactics which she consciously uses to empower herself and achieve what she wants by the end of the novel. In light of the theories of Joan Riviere, this paper intends to illustrate how (in the context of James's narrative strategies) Maggie comes to empower herself without radically intimidating the value structure of the Jamesian patriarchal society and by the use of silence as a mask of womanliness.
\end{abstract}

Keywords: Joan Riviere, Masquerade, Henry James, The Golden Bowl

\section{Introduction}

In Henry James's The Golden Bowl, despite Maggie Verver's love for her husband, her silence, with regards to his affair, is quite enigmatic. The significance of her manner cannot be fully grasped unless we have a thorough knowledge of the perception of women and conventional gender roles in the Jamesian society. The amount of didactic literature aimed at teaching the feminine and masculine roles in the society suggests that for a long time this topic has been a major cause of concern. In the conduct books of the Victorian era, where the traditional roles of women were taught to the female readers, "disinterested kindness and selflessness" (Ingham, 1996, p. 22) were among the most important qualities of any woman.

However, Joan Riviere in 1929 deconstructed this notion by proposing that the "women who wish for masculinity may put on a mask of womanliness to avert anxiety and the retribution reared from men" (1929, p. 303). Thus, by employing such feminine attitudes, women could pave the way for achieving what they desired in a patriarchal society. In a seminal essay, "Womanliness as a Masquerade," which Riviere published in 1929, she remarked that women wore this mask to "be better accepted in social world codified by men" (1929, p. 308). Therefore, even silence, a

(c) AesthetixMS 2018. This Open Access article is published under a Creative Commons Attribution Non-Commercial 4.0 International License (http://creativecommons.org/licenses/by-nc/4.o/), which permits non-commercial re-use, distribution, and reproduction in any medium, provided the original work is properly cited. For citation use the DOI. For commercial re-use, please contact editor@rupkatha.com. 
typical virtuous act of the females, can be understood as a gesture of womanly disguise which is inherently a masquerade.

Thus, on the basis of Riviere's argument, although Maggie Verver's silence primarily seems to be in total relation with the typical virtuous act of the female, a closer look reveals that the case is other than that. While Maggie, like every other typical Victorian woman, is quite obedient and domestic, her resistance to speak can also be regarded as her refusal to conform to the conventional gender roles which demand her to only speak to consent; moreover, according to Rodney Carter who worked on the correlation between silence and power, at times silence "is not necessarily a mark of victimization, but a form of self-assertion" (2006, p. 229). As represented in "BOOK SECOND" of James's novel, Maggie no longer succumbs to the language the Prince and Charlotte choose to excessively use; her stubborn refusal to speak can be recognized as feminine, that is, as a womanly disguise, or a masquerade.

Thus, this paper will argue that Maggie's silence in James's storyworld is not the act of a simpleton or out of weakness, but is cunningly strategic; because it is a sly defense, or a womanly masquerade, for protecting herself from exploitation which her husband and friend were imposing on her in "BOOK FIRST" of the novel. The paper takes to show that despite the infidelity and betrayal shown to her by her husband and friend, Maggie's silence and quietness are, according to Riviere, not signs of victimhood in the patriarchal society but only tactics which she consciously uses to empower herself and achieve what she wants by the end of the novel. So, this paper will also attempt to illustrate how in the context of James's narrative strategies Maggie establishes her own discourse without radically intimidating the value structure of the Jamesian patriarchal society, but by the use of silence and a mask of womanliness.

\section{Joan Riviere's Theory of Femininity as a Masquerade}

What Riviere calls masquerade is, to put it simply, a person who is "mainly heterosexual" yet who "plainly display[s] strong features of the other sex" (1929, p. 303). To support her definition, Riviere quotes from Sandor Ferenczi in First Contributions to Psychoanalysis (1994), and then concludes that "homosexual men exaggerate their heterosexuality as a 'defence' against their homosexuality" (Riviere, 1929, p. 303). And Riviere considers femininity itself like an apparatus which makes it possible for the women wishing to hide their masculine traits, like a desire for power, to "put on a mask of womanliness" (1929, p. 303). According to Woodward, this female disguise looks like "submission to the dominant social code, when in actuality it is disruptive and resists patriarchal norms" (1989, p. 125). Hence, the women who act according to the conventional gender roles may in fact destroy the power structure by acting in a feminine way while they also aim at meeting their personal wishes and desires, a priority which is denied a married woman in the patriarchy. In a patriarchal society, following one's desires freely is only acceptable for men. So, to speak for Leslie Bow, Riviere's theory of masquerade "suggests that excessively feminine behavior unconsciously disguises women's phallic desires" which originate "from a woman's desire to placate masculine authority for the affront of her own intellectual display" (2001, p. 53). That being the case, a woman's feminine behavior cannot simply be considered an ordinary occurrence; perhaps one needs to look at typical feminine behavior as a statement from a strongheaded woman who is not willing to give up on her hopes and desires in a patriarchal world and is inclined to follow her wishes, just like every other man in patriarchy, even under an excusable mask that is covering her authentic subjectivity. 
To better understand Riviere's idea of masquerade and womanliness, let's take a closer look at her own definition of womanliness. She argues that it is

assumed and worn as a mask, both to hide the possession of masculinity and to avert the reprisals expected if she was found to possess it-much as a thief will turn out his pockets and ask to be searched to prove that he has not the stolen goods. The reader may now ask how I define womanliness or where I draw the line between genuine womanliness and 'masquerade'. My suggestion is not, however, that there is any such difference; whether radical or superficial, they are the same thing. The capacity for womanliness was there in that woman. (1929, p. 38)

Therefore, she finds womanliness synonymous with masquerade: being a woman is itself only a lack which still has to fill the gap in the subjectivity of women. In a recent article, Mary Ann Doane remarks that "Masquerade ... doubles representation; it is an excess of femininity subverting the masculine structure of the gaze, the law and the word" (2003, p. 66). Through keeping up the masquerade, womanliness gets rid of being the object of misuse in the genderbiased conduct of the patriarchal world, and therefore can destroy the whole structure of gaze practiced by the male subject. Thus, to be a woman means to be both a subject and object and yet to be none of them at the same time.

Making use of Riviere's theory, Judith Butler also has tried to expand and redefine masquerade:

Women are said to "be" the Phallus in the sense that they maintain the power to reflect or represent the "reality" of the self-grounding posture of the masculine subject, a power which, if withdrawn, would break up the foundational illusions of the masculine position [...]. Hence, "being" the Phallus is always a "being for" a masculine subject who seeks to reconfirm and augment his identity through the recognition of that "being for". (1990, p. 61)

Butler takes this for a "heterosexual comedy" (1990, p. 63) where women have no other option but masquerading. For Butler, "all gender ontology is reducible to the play of appearance" (1990, p. 63). Thus, as mentioned by Butler, since in patriarchal systems it cannot be comprehended for women to have the phallus, being a powerful woman who seems to acquire phallic desires can only be considered as being the phallus. This results in being seen as only a façade that is covering the womanliness of females. Riviere refers to this form of pretending when she mentions a housewife capable of repairing things, yet when meets a handyman she has "a compulsion to hide all her technical knowledge” (1929, p. 307) and only gives away her comments as simple suggestions in "an innocent and artless manner, as if they were 'lucky guesses"'(1929, p. 307). Therefore, just as stated by Butler, the housewife tries not to provoke any form of insecurity in the handyperson, so that he still feels superior next to a woman, simply because he is a man. Also, the skilled woman needs to downplay her expertise due to being a woman in order to maintain the equilibrium of the society.

Citing a research by Ernest Jones, Riviere points to a type of homosexual women who "while taking no interest in the other women, wish for 'recognition' of their masculinity from men and claim to be the equals of men, or in other words, to be men themselves" (1929, p. 305). Yet Riviere adds that a woman belonging to this group would still publically "acknowledge her condition of womanhood" (1929, p. 305). Moreover, these women are "excellent wives and mothers, capable housewives; they maintain social life and assist culture; they have no lack of 
feminine interests" (1929, p. 304). However, Riviere still indicates that a woman belonging to this bunch is "a particular type of intellectual woman" (1929, p. 303).

\section{Discussion}

Even though all the three main characters in James's novel are seemingly self-assured, and willing to make sacrifice for the achievement of their goals, the difference is between the strategy Maggie uses for the purpose and the means to which the Prince and Charlotte appeal. Maggie's strategy is (womanly) silence, and so she keeps her feminine mask throughout the play, while her opponents act like male characters hidden in both male and female bodies; the same as phallus which is signified in the binary system because of its visibility, the Prince and Charlotte, too, display their feelings and self-doubts too blatantly. Just as asserted by Riviere in her seminal essay, Maggie wears this mask of womanliness to be accepted in both familial and societal situations, and it is by the use of this weapon that she sees the opportunity to endear herself both to her husband and father. So it is precisely by the use of this strategy of silence that she can pave her way for undoing her husband and Charlotte's plan and imposing her own discourse on them.

Despite her intentions to win her husband back and restore him to his "proper" place, Maggie violates the gender system by defending it. A society that only accepts the man as the family's breadwinner and finds it hard to manage or come to terms with the life of a single mother surely does not embrace the idea of a woman manipulating her husband. In this type of society the woman is the gullible creature who is only to stay at home and take care of the children, and any form of connection between her and power is considered immoral or diabolic. While all Maggie's efforts are to win her husband and her young infant's father back for restoring her family to full health and happiness, the means that she uses for the purpose are quite unorthodox for a woman. Her unique method of solving her spousal conflict is in line with Riviere's theory of femininity as masquerade, where she indicates that women make use of typical feminine behaviors in order to preserve their status from the risk of patriarchy which insists on its survival by eliminating the woman from the discourse of power.

\section{The Innocence at the Crossroads}

A woman in the Victorian times was seemingly stereotypically deemed as the basic component of what Ingham calls the "construction of femininity" (1996, p. 76), for she was taken either for a wife or for a mother. In "BOOK FIRST" of James's novel, Maggie is depicted as a stereotypical Victorian woman who is rarely more than a devoted wife and daughter caring only for her domestic chores; and is, like any other woman, inherently pure and devoid of logical recognition. To speak for James himself, "She wasn't born to know evil" (1984, p. 44), and is "absolutely good and sweet and beautiful" (1984, p. 393) and is "incapable of any plan to hurt a hair of her head" (1984, p. 40). Like other girls in the Victorian era, after the death of her mother she comes to fully devote herself to her father. At the outset of the story she is portrayed like a servant to her father who protects him "as if she were more than a daughter" (James, 1984, p. 74), for she does "for him more than he knew" (James, 1984, p. 74). Thus, her close relationship with her father, which some critics have taken even for incestuous, can also be discussed in the light of Riviere's theory. So it is understandable why this critic should believe that unresolved issues of the kind of Oedipus Complex, such as a complex for an affair with one's father, is among the reasons why some women would choose masquerade as a form of behavior. 
There are other critics too who have judged Maggie as the portrayal of a typical Victorian woman, because when she faces with an unfair situation she can neither stand up for herself nor can do like a "fighter" (Boockoff, 2015, p. 37) or even can show "overt rebellion" against it (Phipps, 2011, p. 245). Donatello Izzo goes as far as to state that Maggie is, like any other female character in James's fiction, "fully consistent with the Victorian images of women who are submissive, silent, reified, victimized, sacrificed" (2001, p. 27). However, when Maggie becomes aware of the affair between her husband and her friend, her awareness causes her to reevaluate her position, reinvent herself through a redefinition of her gender, and become more self-conscious of the potential power inherent in her femininity. In the very first chapter of "BOOK SECOND" of James's novel there is a radical turning point in his story-line. Here the action of James's novel exemplifies what Suzie Gibson calls "a revolution in her [Maggie's] consciousness" (2015, p. 4), for she starts taking control of her situation and so her discourse is no longer naïve and subordinated to that of her husband and friend, where she imposes her newly super-ordinated discourse on them with "an infinite sense of intention" (James, 1984, p. 225). James refers to this moment as a "greatmoment ... for conscious repossession" (James, 1984, p. 226).

After her husband's betrayal, Maggie decides to become independent in the prioritization of her own needs. While she firstly seemed an obedient girl who shied away from any crisis or conflict, when she is faced with the betrayal of her husband and friend, she no longer finds them depressing while depressing is "the form indeed in which she had mainly known them" (James, 1984, p. 136). Therefore, one can understand why James says Maggie sees this moment as a "high degree exhilarating" (James, 1984, p. 136). The guess of this research is that Maggie now succeeds in the achievement of her goal not "through open persuasion" (Haralson, 2009, p. 96) which can be deemed as an action through language, but by "an exceedingly subtle art of emotional diplomacy" (Haralson, 2009, p. 96). This diplomacy is in line with what Riviere believes is the ultimate characteristic of femininity, which is a "device for avoiding anxiety" (1929, p. 307) and means to behave in one way but to intend that the things seem differently. Riviere also calls this masquerade of femininity an art which the more powerful women choose to acquire in order to meet their needs and wishes in a society that prohibits them from an "open" objection or discussion.

According to Eric Haralson, many of James's female protagonists face problems due to living in "a society ruled by more conventional values" (2009, p. 431). And yet what distinguishes Maggie from James's other female protagonists is perhaps her decision to come up with a plan which not only helps her to get what she wants but still does not cause the disruption of the conventional values of her social and familial life. Although some critics have considered Maggie's successful effort as an "artistic form" (Craig, 1982, p. 140) or "[a] disrupt[ion of] the social order" (Gibson, 2015: 4), Priscilla Walton has elaborated more on this matter by calling her achievement the result of the creation of a "feminine" script (1992, p. 144). What makes Maggie's strategy really feminine is that, as it is expressed by Riviere, she puts on a mask of womanliness and excess femininity as "an unconscious attempt to ward off the anxiety which would ensue on account of the reprisals .... anticipated from the father-figures after ... [an] intellectual performance" (1929, p. 305). John Kinard points out that "ironically, the very thing which allowed Maggie access to the knowledge of what, to her, constituted a betrayal--the crack in the bowl--is the very thing she wishes to seal up" (2014, p. 44). In the same line of argument, in a society where women are thought to behave as if their ignorance were bliss, Maggie thrives to go against the grain. Kinard argues that while Maggie may appear to hide the crack in the bowl (of her marriage with the Prince), under the surface she manages not only to repair it but also to rebuild it in a way that it satisfies her personal wishes. Thus, the broken bowl can also be referring to the shattering of the 
conventional form of marriage in James's society and a reconstruction of gender and its consequences in married life.

\section{Artful Femininity: Undercover Intelligence}

In Riviere's article we read that “The exhibition in public of [a woman's] intellectual proficiency, which was in itself carried through successfully, signified an exhibition of herself in possession of the father's penis, having castrated him" (1929, p. 305). Similarly, in the James's society, any woman who demonstrates her authority publicly will be "seized by horrible dread of the retribution" (1929, p. 305-6) from her father or any male figure who seems to be threatened by her empowering gesture. Thus, what she has to do is to "offer herself to him sexually" (1929, p. 306) in order for a "propitiating [of] the avenger to endeavor" (1929, p. 306). This means that by complying with the established gender roles, the woman behaves like a sexual being whose only job is a sexual duty to appease the needs of the man. Yet, it should be mentioned that by this the typical female does not intend to make herself safe in the situation but to "make sure of [her] safety by masquerading as guiltless and innocent" (Riviere,1929, p. 306). And it is "a compulsive reversal of her intellectual performance" which Riviere calls a "double-action" (1929, p. 306).

Maggie, too, is in possession of that dual personality to which Riviere refers, because, to speak for Siqi Jöttkandt (2008), she "accomplishes her will, while at the same time remaining faithful to....ethical premises” (p. 177). Thus, she can demonstrate her power to transform the situation without being conceived as a vicious woman who exploits her social and familial status to fulfill her wishes. Sunita Singhal is of the opinion that in the Jamesian world the characters are expected to be "as fully conscious as they possibly can" (2015, p. 161) in order to have the "maximum ability to do well" (2015, p. 161). As the most self-conscious character in the novel, Maggie guarantees herself a successful plan by being aware of the limitations of her performance, and chooses masquerading so that she can still carry her plan forward without causing any unwanted attention.

What makes Maggie a unique character in James's fiction is what Riviere names performing a "double action." Maggie presents herself as a good-natured friend and wife while at the same time making every possible effort to break the union between the Prince and Charlotte who in the public eye are only good friends. For this reason and also for her reluctance to reveal the love affair of the Prince and Charlotte to others, she has no other choice than behaving as a respectable high class Victorian woman who cherishes both her husband and her step-mother, while each of her moves, dialogues, or silence is a step for opening the room for maneuver as she tries to defeat their plan to remain in affair. Even though some critics, such as Lucy La Farge (2011), believe that for Maggie "deception is a normal state of affairs" (p. 115), it should be noted that for her to be morally correct is perhaps not always synonymous with to be right. Maggie does her best to save her marriage, and even if she has to make a handful of "deceitful" moves to achieve her purpose, she will not thoroughly feel ashamed of it. As a woman who begins to realize her equity in partnership, she manages to take charge of her domestic life, and we see her en route for rendering herself an independent female who needs the consent or cooperation of no man to achieve her personal wishes. Joseph Kronick indicates that in James's novel "to be safe .... is to hide oneself from exposure" (2016, p. 8). However, Fanny Assingham's advice to Maggie is to "open .... To what's called Evil-with a very big E: for the first time in her life. To the discovery of it, to the knowledge of it, to the crude experience of it .... To the harsh bewildering brush, the daily chilling breath of it," which will make Maggie "by way of a change, understand one or two things in the world" (James, 1984, pp. 294-95). Therefore, if one considers Maggie's "insincerity" 
as a necessary step for her to become a more self-contained woman, the reserved quality of her approach is only to ensure that her plan will work out without any backlash from the public or the other characters involved.

Maggie's thriving to realize her plan is an indication of her feminist attempt to become a self-reliant individual in an era when women who fought for liberation were stigmatized. Even if Charlotte seems to be a more liberal woman than Maggie since she is a single woman who likes her freedom to travel and party without any supervision, the clash between the two is "a fierce struggle between femininity and authority" (Coulson, 2009, p. 59). While Maggie appears to be more conservative than Charlotte, the fact that she is "more closely aligned - more compliant with social authority" (Coulson, 2009, p. 59) makes her superior to Charlotte who continues to spell out her problem with the change in Maggie's attitude. Susan Winnett believes that "whoever controls the surface controls the depths" (1993, p. 216); therefore, Maggie's reluctance to speak in public about the affair wins her the opportunity to control the hidden affair as well. Coulson is of the opinion that Maggie's superiority is due to having a higher financial and social status than Charlotte which consequently gives her more freedom to find ways to obtain what she wants. Notwithstanding, the fact that the subject's gender also influences how much power s/he can gain in a society should not be neglected.

Additionally, Donatella Izzo reasons that it is the "possession of knowledge that enables Maggie to achieve her ends, just as Charlotte's lack of knowledge is her main punishment" (2008, p. 358). What Izzo means might simply refer to the knowledge about the love affair between the Prince and Charlotte, while it can also be the knowledge as to how to keep silent in this critical situation and slyly to put on a masquerade as a way out of it. Perhaps one should think of both Charlotte and Maggie as the underdogs of the patriarchy who compared to the male characters enter into less alliance with the social power. If one looks at this issue from this aspect, one realizes that Maggie's triumph over the problem, is, in contrast to Charlotte's failure, only the result of seemingly accepting her inferior status in the society.

\section{Passivity as Nonviolent Resistance}

Another significant difference between Maggie and Charlotte is that the former outperforms the latter through a strategy of silence and seeming passivity, and it is via her radical reticence that Maggie wins the struggle. Haralson takes the view that "Maggie eventually masters her situation by discovering the power of passivity" (2009, p. 93) since she "does absolutely nothing with her new knowledge except hold onto it, and in this way she controls the entire situation" (2009, p. 92). Maggie's reluctance to disseminate her information about the affair is in line with the anecdote mentioned by Riviere where a skilled woman does not demonstrate her abilities in order to preserve her humble status in a male-dominated world. Maggie, too, needs to keep her meek personality on the surface in order to eventually break the ties between her husband and her stepmother without tainting the family's name in the society. By taking whatever action she deems due, seeming passivity included, she puts herself in charge of the situation and is therefore responsible for the outcomes; while Charlotte and the Prince are simply played by Maggie and thus become the "perfectly passive pair" (James, 1984, p. 157).

Analogous to Riviere's idea that these women have an intellectuality which might not be quite apparent, Maggie is a self-proclaimed thinker, a trait which was far from feminine at the Victorian era. But it is right that her winning card is masking her true perceptive self under a typical innocent woman. The woman needs to show her masculinity in patriarchal society "as a 
'game,' as something not real, as a 'joke”" (Riviere, 1929, p. 308); the woman, therefore, "cannot openly take up a firm straightforward stand; she feels herself as it were 'acting a part,' she puts on the semblance of a rather uneducated, foolish and bewildered woman, yet in the end always making her point" (Riviere, 1929, p. 308). Maggie points out to this fact where she confides to Fanny that "it's my nature-I think" (James, 1984, p. 399). What gives her the upper hand in this battle is, as she tells Fanny, that Prince and Charlotte had "thought of everything but that. They thought of everything but that I might think" (James, 1984, p. 399). While some critics have called her "inhuman" (Blackmur, 1983, p. 224) or "sadistic" (Freedman, 1990, p. 234) due to her "combination of cruelty and boundless knowledge" (Freedman, 1990, p. 234), Maggie's influential mode of operation is that she modifies the situation to her own benefit by way of manipulating others through hesitation. She blatantly refers to her own manipulative behavior by commenting: "that's how I make them do what I like" (James, 1984, p. 283). Jöttkandt, too, believes that "Maggie's plan ... is simply to continue to behave as though she were indeed so stupid" (2008, p. 177). What gives Maggie the privilege to outscore her opponents is that she not only controls and organizes her own thoughts, but she also controls the thoughts of other characters in the novel. Even James refers to this moment as a time which does "represent our young woman's consciousness of a recent change in her life" (James, 1984, p. 223).

As presented in the novel, Maggie's knowledge of the affair does not affect her tactic of passivity; she is surely not going to be unassertive about an affair that is potentially ruining her life. The fact that she implicitly refers to this issue many times in the novel, especially during her talks with Fanny, indicates that she is once again making use of masquerading as the way to tackle the problem. While the main subject of James's novel is the manner in which Maggie approaches the affair between her husband and her stepmother, Maggie's bold reticence about it signifies her conscious scheme not to reveal her true intentions by voicing the problem even to her closest friend. Maggie's style of passive manipulation is to think thoroughly and much about the setback and yet to talk as little as possible as to it, what Kronick calls "a language that is beyond speech" (2016, p. 11), or what Campbell terms "keep her language vague" (2011, p. 118). Brudney, too, believes that "Maggie's struggle is against articulation. The issue is not what she knows but how to control her knowledge" (1990, p. 410). By behaving in her typical manner, she deceives both the Prince and Charlotte into thinking that their plan for hiding their affair is working out perfectly, and she also buys herself more time to come up with a strategy that has the lowest possible risk of failing. Therefore, her seeming passivity in both directing the issue through silent communication and taking smart action to terminate the affair is an indication of her decision to practice femininity as a masquerade for winning in the conflict.

At this point in the novel, Maggie is so self-assured about the success of her disguise that she confides to Fanny that even though she is "tormented" and "helpless," she would stuff her "pocket handkerchief into my mouth, I keep it there, for the most part, night and day, so as not to be heard too indecently moaning" (James, 1984, p. 280). Instead of playing the role of the damselin-distress, she arranges everything in a way to make her plan succeed. Maggie calls it a "midst of miracles of arrangement, half of which I admit are my own" (James, 1984, p. 280). Thus, on the one hand she goes on pretending that she has no clue of a love affair between her husband and Charlotte, but on the other hand she closely watches every move they make while seeming like a good domestic wife. With the control of "patriarchal practice and its traditions of social order, family, aesthetics, sexuality" (Chowaniec et al., 2008, p. 3), the women are robbed of all but one choice: to conceal their true aspirations and desires. She tells Fanny "I go about on tiptoe, I watch for every sound, I feel every breath, and yet I try all the while to seem as smooth as old satin dyed rose-colour" (James, 1984, p. 280). Even when she talks to her nemesis Charlotte, she tries to "look 
as little dangerous .... as abjectly mild, as possible" (James, 1984, p. 287). Many times in the novel Maggie thinks of her clever moves and unabashedly refers to them; she seems confident that it is permissible to do what it takes, even if it is immoral, to save her marriage: "She said to herself in her excitement that it was perfectly simple: to bring about a difference, touch by touch, without letting either of the three, and least of all her father, so much as suspect her hand" (James, 1094, p. 348).

What is thought-provoking about Maggie is also her acknowledgment of the fact that she needs to hide her awareness of "the nature of their struggle" (James, 1984, p. 298) from her husband, since if he becomes conscious that they are in a "high fight" (James, 1984, p. 298), all her plans to defeat him will be destroyed. As stated in the novel, "she was learning almost from minute to minute to be a mistress of shades" (James, 1984, p. 298) and to act in a way that confirms "her supposed stupidity" (James, 1984, 298). Although she was only Adam's little girl in the first part of the novel, after her trust and innocence is shattered, she becomes conscious of the crudeness of the life, and changes to a "much thinking little person" (James, 1984, p. 231), and makes use of "employing passive aggressive tactics" (Haralson, 2009, p. 96) and "pure politics" (Cameron, 1989, p. 85) to make other characters do what she desires. It is Maggie's sly silence that changes the form of the relationship between the Prince and Charlotte and brings the lawfully married couple closer to each other. As mentioned by Eric Haralson, "Maggie's passive aggression, her ability to sit quietly with her knowledge and do nothing about it, transforms each of the major relationships" (2009, p. 93). Through her non-aggressive yet assertive method she not only manages to break up the relationship between the Prince and Charlotte but also persuades Adam to leave with his wife to America, a place far enough to render the possibility of the cheater's affair very unlikely.

\section{The Histrionic Type: Man the Ego Booster}

And yet a further issue of Maggie's masquerading can be analyzed in terms of Riviere's theory: women keep up the masquerade to be attracted by men. Riviere declares that the masquerade is the women's way of attracting the men to themselves without acting in any way promiscuous. It is for the same reason that at the end of the novel when Charlotte and Adam are leaving Maggie and the Prince for America, Maggie asks herself "Is that what I wanted?" (James, 1984, p. 384). This may refer to Maggie's uncertainty about if she feels for the Prince which implies that she has only tried to get him back in order to win Charlotte in the love game. Moreover, this female struggle for catching the attention of the male signifies her position. It is only in the society, where women are taken for sexual beings, that these kinds of competitions may happen. The fact that the women are often taken for men's possessions is evident in James's text where the Prince, upon seeing Maggie for the first time, acknowledges that she is "one of the beautiful, the most beautiful things" (James, 1984, p. 7); he also starts thinking of Charlotte after he sees her as "a cluster of possessions" (James, 1984, p. 27). Thus, Maggie's aim is to become the Prince's object of desire again. She does not simply want him to leave Charlotte, she wants him to have true desire for her too.

As depicted in the novel, the Prince seems to be desired by every woman: "This was HIS, the man's, any man's, position and strength - that he had necessarily the advantage, that he only had to wait with a decent patience to be placed .... in the right" (James, 1984, p. 28). However, when Maggie takes over the game, she only needs to wait for her preys to fall in her trap. While in the first BOOK of the novel Maggie does not seem radically to desire her husband and only thinks of her as a precious object which is only "a part of [Adam's] collection .... an object of beauty, an 
object of price" (James, 1984, p. 8), after realizing that there is a possibility of an affair between the Prince and Charlotte, she involves herself in a meticulous process of caring for him. The novel reads:

she never admired him so much, or found him heart-breakingly handsome, clever, irresistible, in the very degree in which he had originally and fatally dawned upon her, as when she saw other women reduced to the same passive pulp that had then begun, once for all, to constitute her substance. (James, 1984, p. 91)

Similar to Maggie, who seems to be aware of Charlotte's superiority in terms of looks, Riviere mentions how her patient was "conscious of rivalry of almost any woman who had either good looks or intellectual pretensions. She was conscious of flashes of hatred against almost any woman with whom she had much to do" (1929, p. 309). Yet, she had a good relationship with close acquaintances due to unconsciously "feeling herself superior in some way to them" (Riviere, 1929, p. 309).

According to Riviere, such a woman is not afraid to claim sexual enjoyment and can decide to "obtain and experience the enjoyment and pleasure" (1929, p. 307); however, the satisfaction which may come from it is in the "nature of a reassurance and restitution of something lost, and not ultimately pure enjoyment" (1929, p. 307). This is because it is "The man's love [which] gave her back her self-esteem" (Riviere, 1929, p. 307). Maggie, too, when is trying to persuade her father to leave forever confesses her selfishness to him by saying "Ah it's just [Amerigo] who's my selfishness. I'm selfish, so to speak, for him” (James, 1984, p. 503). Another verification from the text is that Maggie's affection for Prince begins to "vibrate with a violence" (James, 1984, p. 316) only after she realizes that there is a chance she is losing her husband to another woman who seems to be more aesthetically pleasing. She fights for her husband, perhaps not out of love, but out of narcissism to make her feel loved and wanted. Therefore, her decisiveness to erase Charlotte from their lives is related to her need to have the Prince only to herself. Maggie not only feels betrayed by her husband and friend but also suffers from insecurity, since having lost her husband to a better-looking woman has rubbed her of all her confidence. Therefore, by persuading Adam to leave for America with Charlotte, she can at least get back the self-esteem she is used to acquire. At the end of the novel, Maggie affirms Charlotte's significance in the fortune of the American beauty herself on the one side and the Prince and Maggie on the other, for she tells the Prince that the beauty is "not only making her own life, but she's making ours" (James, 1984, p. 582). This too can be interpreted in the light of Riviere's theory on feminine rivalry. Maggie states "It's as if her unhappiness had been necessary for us-as if we had needed her, at her own cost, to build us up and start us" (James, 1984, pp. 579-580). So it is safe to say that Maggie's jealousy to have the Prince exclusively to herself takes deep roots in her which only finds opportunity to surface after the finish of the Prince-Charlotte affair. Taking this moment for the occurrence of Maggie's full maturity, Fanny Assingham comments that she "has begun to live" (James, 1984, p. 208).So, if being a woman is synonymous with masquerade, then living in this sense can only be comprehended as having the freedom and will to do what a woman wishes. Therefore, Maggie's womanliness can only be assured if she can get her husband back to give her again the assurance that she deserves of having him and of being loved and wanted by him.

However, it should be taken into consideration that what gives Maggie confidence to have the Prince as her husband seems to be more related to his good looks. As noted by Riviere, these women tend to be in search of pleasure, and Maggie seems to get satisfaction from having a goodlooking husband. Even prior to her knowledge about his affair with the American beauty and shortly after her marriage to him, she confides to Fanny that "even should he some day get drunk 
and beat her, the spectacle of him with hated rivals would, after no matter what extremity, always, for the sovereign charm of it, charm of it in itself and as the exhibition of him that most deeply moved her, suffice to bring her round" (James, 1984, p. 126).

Moreover, Maggie's straightforward way of describing her husband in a sexually-charged manner is very unusual at a time when Victorian conventions used to construct the woman as "an object to be looked at rather than an actor or a self" (Beetham, 1996, p. 78) and to locate "femininity as object in a sexual dynamic where the gaze was assumed to be male" (Beetham, 1996, p. 39). However, in James's novel the design of this gaze is in opposition with Beetham' description, for it is Maggie who often gazes (psychoanalytically/realistically) at the Prince and Charlotte. Grossman considers Maggie's supremacy in regard to her battle with the other characters as a "scopophile's dream" (1994, p. 318). Grossman states that Maggie is "the active observer who can change her situation and surroundings merely by looking-by passively looking a certain way and by actively looking at those around her" (1994, p. 318). She is thus "simultaneously a seer and an object of the vision of the other" (Grossman, 1994, p. 312). Therefore, regardless of Maggie's gender, it is she who has the privilege both of having the subject position and gazing at her objects while outwardly she is just a woman who is inevitably always inferior to men.

\section{Maggie the Anarchist}

Aware of the social patriarchy in James's society which more than often gives superiority to the Prince over Maggie, she realizes that she needs to find a way to disrupt it in consequence of which she hopes she can ultimately get her husband back to herself. According to Izzo "what Maggie clearly knows is not so much her husband's adultery .... as the mechanisms of his power over her" (2008, p. 358). Izzo also contends that Maggie's "self-awarely deceptive performance .... of that Jamesian stereotype, the American innocent ....[is] predicated on an awareness not just of her own self, but of the crude dynamics of love relations as power relations" (2008, p. 358). Therefore, the connection between power and gender becomes so apparent that clearly the love relationships become affected by it as well. Maggie begins to notice that her inferiority is due to her social status as an upper class woman which results in her inferiority in standing against her husband's wrongdoings; however, "characters who can reason through love's difficulty, such as Maggie Verver, wield the most power" (Gibson, 2015, p. 2); while in BOOK FIRST of the novel she is depicted as a virtuous devoted girl, in BOOK SECOND she gradually becomes aware of her position both in her family and society, and decides to pursue what she wants. So, she is smart enough to realize that before taking any bold action, she has to find a solution to the problem, a solution which does not put her status or reputation in jeopardy.

Izzo believes that what Maggie does throughout the novel is showing "the final superseding of patriarchal gender ideology" (2008, p. 358) by depicting how she manages to empower herself and deconstruct "the inherent sex and power structure" (2008, p. 358) of the patriarchal world. Yet, others have criticized Maggie's way of handling the situation through feminine passivity since it "works toward the characters' conformity to a normative vision of marriage" (Seltzer, 1984, p. 150). However, it should be noted that what makes Maggie a feminist icon is precisely showing the other side of feminism which concerns itself with the female's persuasion of personal goals and wishes while maintaining her domestic sphere as well. Although some might consider Maggie winning in the game a pathetic restoration of a failed marriage, her assent to try for the fulfillment of her personal needs regardless of the restraints put on her by the 
patriarchal society empowers her to an extent that it even compels other characters to follow her plan.

\section{Conclusion}

Therefore, in line with Riviere's argument, even though Maggie Verver's silence initially appears to be a demonstration of feminine conformation to the conventional gender roles of the Victorian era, a more detailed examination of James's story indicates that despite his character's seemingly conformable attitude, her reluctance to directly address the issue of her husband's affair with Charlotte Stant is her strategic method of masquerading in order to establish her discourse through managing to break up their affair. While in BOOK FIRST of the novel, she gives the impression of being a typical simple-minded Victorian woman, when faced with the infidelity of her husband and friend, she achieves her objective in transforming herself into a new personality. However, it is her clever decision not to disrupt the equilibrium of the social patriarchy that leads her to success. To reach this end, she uses what Riviere calls "the womanly disguise" which aids her in the maintenance of her seemingly inferior position in both her society and her family and in the meanwhile following her phallic pursuit of wishes; she keeps on being the good-natured obedient wife and mother, but under this masquerade she makes use of her strategic intellectualism, by way of silence, to break off the relationship between the Prince and Charlotte. Maggie is cognizant of the necessity to hide her true intentions from everyone, since if they are publicly discussed, she will be punished for trying to cunningly defeat a man. It should also be taken into consideration that the epiphany that leads to Maggie's reinvention of herself and becoming a powerful woman in a male-dominated world is her realization that she has a formidable opponent who is winning the affection of her husband. As stated by Riviere, this struggle for the attraction of the man is one of the main reasons why the woman uses masquerade to win the former's attention without looking promiscuous. Therefore, through fighting for her husband, Maggie is fighting simply to restore her own confidence. Realizing the power system of the patriarchal society which gives superiority to the Prince over her, she also realizes that she needs to find a way to disrupt this system in consequence of which she hopes to ultimately get her husband back to herself. Although it may seem that her goal to maintain his marriage to an adulterous person is pathetic, what distinguishes her try is the fact that along this process she reinvents herself and becomes a fully grown-up and confident woman who appreciates that she has the power to control her domestic life, which is quite important to her. Thus, in a patriarchal society where the woman is obliged only to abide, her refusal to comply makes her into a rebel who by the use of masquerade achieves her personal aims without putting her image at high risk.

\section{References}

Beetham, M. (1996). A Magazine of Her Own? Domesticity and Desire in the Woman's Magazine 180o-1914. London: Routledge.

Blackmur, R.P. (1983). Studies in Henry James. V., Makowsky (Ed.). New York: New Directions.

Boockoff, E. (2015). Leading Women: Henry James and Feminism in The Portrait of a Lady, The Bostonians and The Golden Bowl. CHP, Ball State University, viewed 19/09/2016, http://vc.bridgew.edu/honors proj/85.

Bow, L. (2001). Betrayal and Other Acts of Subversion: Feminism, Sexual Politics, Asian American Women's Literature. Princeton, N.J: Princeton University Press. 
Brudney, D. (1990). Knowledge and Silence: "The Golden Bowl” and Moral Philosophy. Critical Inquiry 16, 397-437.

Butler, J. (1990). Gender Trouble: Feminism and the Subversion of Identity. New York: Routledge.

Cameron, S. (1989). Thinking in Henry James. Chicago: University of Chicago Press.

Campbell, S. (2011). Say “Nothing” and Meaning "Everything” in The Golden Bowl. Arizona

Quarterly: A Journal of American Literature, Culture, and Theory 67, 101-125.

Carter, R.G.S. (2006). Of Things Said and Unsaid: Power, Archival Silences, and Power in Silence. Archivaria 61, 215-233.

Chowaniec U., Phillips U., and Rytkönen M. (Eds) (2008). Masquerade and Femininity:

Essays on Russian and Polish Women Writers. Newcastle: Cambridge. Coulson, V. (2009). Henry James, Women and Realism. Cambridge: Cambridge University Press.

Craig, D.M. (1982). The Indeterminacy of the End: Maggie Verver and the Limits of Imagination. Henry James Review 3. 2, 133-44.

Doane, M.A. (c1982; 2003). Film and the Masquerade: Theorising the female spectator. In A., Jones (ed.) Feminism and Visual Culture Reader. London and New York: Routledge, 6o-71.

Freedman, J. (1990). Professions of Taste: Henry James, British Aestheticism and Commodity Culture. Stanford: Stanford University Press.

Freud, S. (1991). On Sexuality: Three Essays on the Theory of Sexuality and Other Works. New York: Penguin.

Gibson, S. (2015). Love's Negative Dialectic in Henry James's The Golden Bowl. Philosophy and Literature 39, $1-15$.

Grossman, J. (1994). “It's the Real Thing”: Henry James, Photography, and The Golden Bowl. The Henry James Review 15, 309-328.

Haralson E., Johnson K. (2009). Critical Companion to Henry James: A Literary Reference to His Life and Work. United States of America: Facts on File.

Ingham, P. (1996). The Language of Gender and Class: Transformation in the Victorian Novel. London: Routledge.

Irigaray, L. (1985). This Sex Which Is Not One. Ithaca, N.Y: Cornell University Press.

Izzo, D. (2008). Nothing Personal: Women Characters, Gender Ideology, and Literary

Representation. In G.W. Zacharias (ed.) A Companion to Henry James. United Kingdom: Blackwell, 343-359.

Izzo, D. (2001). Portraying the Lady: Technologies of Gender in the Short Stories of HenryJames. Lincoln: Nebraska University Press.

James, H. (1984). The Golden Bowl. London: Dent.

Jöttkand, S. (2008). Truth, Knowledge, and Magic in The Golden Bowl. In: Zacharia GW (ed.). A Companion to Henry James. United Kingdom: Blackwell, 176-192.

Kinard, J. (2014). 'Precious Objects': Strange 'Things' in James and Wharton. Master's, University of South Carolina, viewed 19/o9/2016, http://scholarcommons.sc.edu/etd/2931.

Kronick, J. (2016). The Betrayal of Love: The Golden Bowl and Levinasian Ethics. The Henry James Review 37, 1-19.

La Farge, L. (2011). Caught in the Snare of Deception: An Exploration of the Psychology of Being Deceived through Two Novels of Henry James. The Psychoanalysis Quarterly 80, 91-120. 
Phipps, G.A. (2011). Desire, Death, and Women in the Master-Slave Dialectic: A Comparative Reading of Hegel's Phenomenology of Spirit and Henry James's The Golden Bowl. Philosophy and Literature 35, 233250.

Riviere, J. (1929). Womanliness as a Masquerade. International Journal of Psychoanalysis 10, 303-313.

Seltzer, M. (1984). Henry James and the Art of Power. Ithaca: Cornell University Press.

Singhal, S. (2015). Feminist Consciousness in the Select Works of Henry James. PhD, Chaudhary Charan Singh University, viewed 19/og/2016, http://hdl.handle.net/10603/45212.

Walton, P.L. (1992). A Mistress of Shades: Maggie as Reviser in The Golden Bowl. Henry James Review 13, $143-53$.

Winnett, S. (1993). Terrible Sociality: The Text of Manners in Laclos, Goethe and James. Stanford: Stanford University Press.

Woodward, K. (1989). Youthfulness as a Masquerade. Discourse 11, 119-142.

Ali Taghizadeh is an assistant professor at the English Department of Razi University, Kermanshah, Iran. He has a Ph. D. in "American Studies" from John F. Kennedy Institute for North American Studies of Free University of Berlin. At the Graduate School of his department he teaches fiction, American literature, Shakespeare, and literature in linguistics. His main research interests are fiction, literary theory, dramatic studies, and literature in language. He has translated J. Hillis Miller's On Literature into Persian, and has published several research articles both in English and in his mother tongue.

Forough Emam, a PhD student in English Literature in Razi University, has presented several articles in National and International conferences including International Film Studies and Cinematic Arts Conference, TELLSI, etc. Her areas of interest include American Drama and Gender Studies. 